\title{
CCAAT Enhancer Binding Protein Gene Mutation
}

National Cancer Institute

\section{Source}

National Cancer Institute. CCAAT Enhancer Binding Protein Gene Mutation. NCI

Thesaurus. Code C141251.

A change in the nucleotide sequence of a CCAAT enhancer binding protein family gene. 